\title{
IFRS Adoption Impact On Financial And Accounting Information Quality: An Exploratory Study On Moroccan Petroleum And Gas Sector
}

\author{
Anass Cherti \\ Department of management \\ Faculty of Legal, Economic, and Social Sciences, Tangier, Morocco \\ E-mail: cherti.anass@gmail.com \\ Houria Zaam \\ Department of management \\ Polydisciplinary Faculty, Tetouan, Morocco \\ E-mail: zaamhr@yahoo.fr
}

Received: March 20, 2016 Accepted: April 7, 2016

doi:10.5296/ber.v6i1.9184 URL: http://dx.doi.org/10.5296/ber.v6i1.9184

\begin{abstract}
The balance of International Financial Reporting Standards (IFRS), after ten years of their implementation, has reflected a positive perception of its impacts on the function "finance and accounting" of companies and issuers. Those companies and issuers observe, in a large majority that the transition to IFRS has increased the quality and the homogeneity of the information produced and the rapidity of their establishment. Unfortunately in academic research, such studies remains not clear as most publications front IFRS adoption impact in general manner which concern all sectors at the same study.

The purpose of this article is to present the results of an empirical study of three petroleum and gas companies listed in the Casablanca Stock Exchanges (CSE), to measure the impact of the IFRS adoption on financial and accounting information quality in Moroccan petroleum and gas sector.

The released results show that this impact is positive for the petroleum and gas sector and the majority of the accounting and financial variables of this sector under IFRS dependents on
\end{abstract}


those variables under the General Standardization Code of Morocco (GSCM).

Keywords: International Financial Reporting Standards, General Standardization Code of Morocco, Petroleum and gas sector, Financial and accounting information

\section{Introduction}

To develop its international competitiveness, Morocco must be adapted to some requirements such as: Internationalization, the evolution of investor's needs changes in the standards of accounting and finance... Indeed the benefits of IFRS meet largely the requirements imposed by the international market(Elhamma, 2012). Thus from 2008 Morocco was opened to IFRS, by forcing the financial institutions to publish their consolidated financial statements under IFRS and by allowing the non-financial groups optionally to present the financial and accounting communications under IFRS.

In other part, the petroleum and gas sector in the 21 st century presents many challenges ("Oil and Gas," 2002). Demand for energy and petroleum products continues to increase, prices fluctuate constantly, which mark a geopolitical uncertainty, and access to reserves is increasingly difficult. To deal with these challenges, the petroleum and gas companies are looking for ways to increase the productivity of their reserves, to use their assets effectively, to adapt to the international accounting and financial requirements, to enter into strategic partnership agreements, improve compliance and produce more downstream profits(CGI, n.d.). All these goals must be achieved while respecting the security and sustainable development.

Given the backdrop of the continued decline in petrol prices, it would however question the future of Moroccan petroleum and gas sector (Bouithy, n.d.). If the dip of petrol continues, it will affect the sector in Morocco in sense that could push investors to be cautious. Thus the rapidly changing and the dynamic activity of that sector excited us to make our investigation on the petroleum and gas sector.

The Casablanca Stock Exchange (CSE), which achieves one of the best performances in the region of the Middle East and North Africa (MENA), is Africa's third largest Bourse after Johannesburg Stock Exchange (South Africa) and Nigerian Stock Exchange in Lagos. Africa. It was established in 1929 and currently has 19 members and 81 listed from 22 sectors securities with a total market capitalization of \$75,5 billion in 2007.

The exchange is relatively modern, having experienced reform in 1993. The CSE installed an electronic trading system, and is now organized as two markets: the Central Market and a Block Trade Market, for block trades.

One of listed sectors is the oil and gas sector, according to Research $\&$ Markets ${ }^{1}$ the premier report provides analysis of key opportunities and associated challenges facing Morocco oil and gas industry. Amidst several challenges confronting the oil and gas industry including fall 
in prices, changing market conditions, oil and gas sector risk and shift in competitive landscape, the report provides detailed insights into critical short and long term factors set to shape the outlook. The research work examines the existing infrastructure (EP, LNG, refinery, storage and pipelines assets), market conditions, investment climate and competitive landscape of upstream, midstream and downstream sectors. Detailed information on fields, blocks, pipelines, refineries, storage assets and LNG terminals along with Asset by asset details of all existing and planned projects across Morocco oil and gas value chain are detailed in the report. Key trends, strategies and projects being planned by companies, investors and governments are analyzed along with the feasibility of new projects in Morocco oil and gas markets. Further, expected start up, impact of competing assets in other countries and overall industry developments, investments required and other related information on planned projects is provided in detail. Driven by strong methodology and proprietary databases, reliable projections of oil, gas, petroleum products, coal, and LNG- supply and demand are made to 2025. Detailed outlook of the industry in terms of production forecasts of oil, gas, LNG, LPG, gasoline, diesel, fuel oil along with supporting parameters of primary energy demand, GDP and population are included.

It is also noteworthy that in the last decade IFRS have not stopped evolving, and they have been the subject of several research projects, at an international level (Zehri and Chouaibi, 2013) (Abdullah et al., nd) (Crowley et al., nd) (Daske et al., 2008) (Cieslewicz, 2014) (Sefsaf, 2012), as in the level of our country Morocco (Haoudi, 2015) (Ouezzani and Alami, 2014) (Ahsina et al., 2014). Unfortunately, despite the importance of these studies, they cover all sectors in their analysis and they are not restricted to analyzing the impact of IFRS on one specific sector.

The purpose of this article is to present the results of an empirical study of three petroleum and gas companies listed in the CSE for 6 observations between 2010 and 2015. Those results attempt to answer the following question: What is the IFRS adoption impact on financial and accounting information quality in Moroccan petroleum and gas sector? And what is dependence degree of variables measuring the accounting and financial information quality of Moroccan petroleum and gas sector under IFRS on the same variables on that sector under the GSCM?

This article is organized as follow: Section 1 presents a literature review, in which we will analyze IFRS adoption in the world and in the Moroccan context. Section 2 presents research methodology which contains the sample selected followed by the working hypothesis, and at Section 3 we will check our hypothesis by applying our working model, following a statistical method to present and discus the main results.

\section{Literature Review}

In this first section, we will firstly introduce the adoption and dissemination of IFRS specifically in Morocco (1.1). Then we will see the impact of IFRS on financial and accounting information quality in general, and on Moroccan petroleum and gas sector more precise (1.2). 


\subsection{The Adoption and Dissemination of the International Financial Reporting Standards}

Currently, there are real changes that are operating globally in the fields of finance and accounting. The IFRS adoption which became a reality in all continents, indeed, many countries have made efforts to converge their standards towards IFRS including France for example, other countries such as Australia, New Zealand and Hong Kong have directly adopted IFRS as a national repository. A recent study on IFRS in the world (Housny and Mhamedi, 2014) revealed the following table:

Table 1. The adoption of the International Financial Reporting Standards at the world

\begin{tabular}{|c|c|c|}
\hline Countries & Percentages & Requirements \\
\hline 101 Out of 122 Countries. & $82,79 \%$ & Require public interest companies to adopt IFRS. \\
\hline 57 Countries of 122. & $46,72 \%$ & Require or permit IFRS for SMEs. \\
\hline 16 Countries out of 122. & $12,11 \%$ & Are studying the possibility of adopting IFRS for SMEs. \\
\hline Kustralia, New Zealand and Hong & 3 & Have directly adopted IFRS as the national repository \\
\hline China & 1 & Has made great strides to converge its national repository to \\
\hline IFRS Countries of G20. & $70 \%$ & Have adopted IFRS for almost all listed entities on regulated \\
\end{tabular}

In fact, in our country listed companies have the possibility to publish their consolidated financial statements under IFRS or local standards "Notice No. 5 of National Accounting Council (NAC)". But banking institutions are obliged to prepare their consolidated accounts under IFRS since 2008. Recognizing the importance of IFRS and the contributions of their adoption, Morocco is currently reviewing its national repository the GSC to converge to IFRS on several components(Haoudi, 2015).

Regarding companies listed on the external market (European market and IFRS) there is the obligation of consolidation under IFRS. In fact, during its plenary assembly on 26 May 2005, and in the absence of a national legislation prescribing standards for consolidated financial statements, the NAC issued a legal advice (advice 5). According to this legal advice, persons subject to the obligation to present consolidated accounts or who opt for the establishment of such accounts. They must adopt, either the national standards as prescribed by the methodology adopted by the NAC at its 6th plenary assembly of 15 July 1999, or the international standards agree IFRS and related interpretations as published by the International Accounting Standards Board (IASB) and adopted by the European Union(Ahsina et al., 2014). 


\section{Macrothink}

Business and Economic Research

ISSN 2162-4860

2016, Vol. 6, No. 1

We should mentioned that the NAC drew heavily in its methodology the European Accounting Regulatory Committee (EARC) 99-02 published on 29 April 1999 related to the consolidated statements of commercial companies and public enterprises. The methodology adopted by the NAC appears as one of the most transition repository norms to sustain. Certainly, it is based on accounting policies and standards in Morocco but significantly reduces differences with IFRS related accounts treatments consolidated (Haoudi, 2015). Similarly, Moroccan Securities Ethics Council (MSEC) circular dated on January 2012, amended on 8 April 8 and 1 October, 2013, stipulates in Article III.2.12 whether the financial statements are required one of the following conditions:

- The methodology for consolidated accounts of the NAC, for companies other than credit institutions (Advice 5) or;

- The model provided by the circular of the Governor of Bank Al-Maghrib number 56 / G / 2007 on keeping conditions by credit institutions of their accounts or;

- The repository of the IASB which includes International Accounting Standards (IAS) and IFRS, their annexes, implementation guidelines and interpretations of IFRS Committee, and the Standards Interpretation Committee (SIC).

\subsection{The Impact of IFRS on Financial and Accounting Information Quality}

To present our literature review of the impact of IFRS on Morocco and other countries, we suggest a table (Table 2.) which contains the author's names, countries, year, questions, methods and results. The idea of making a literature review as a table is very useful, because it makes it clear.

Table 2. Literature review of IFRS around the world and on Morocco

\begin{tabular}{|c|c|c|c|c|c|}
\hline $\begin{array}{c}\text { Authors } \\
\text { Alali and } \\
\text { Foote }\end{array}$ & Years & Countries & Question & Methodology & Results \\
\hline 2000-2006 & UAE & $\begin{array}{c}\text { What is the } \\
\text { relevance of the } \\
\text { accounting } \\
\text { information under } \\
\text { IFRS? }\end{array}$ & $\begin{array}{c}\text { Multiple } \\
\text { regression. }\end{array}$ & $\begin{array}{c}\text { Irrelevance of accounting } \\
\text { information under IFRS in } \\
\text { certain period. }\end{array}$ \\
(Alali and Foote, 2012)
\end{tabular}




\begin{tabular}{|c|c|c|c|c|c|}
\hline & & & $\begin{array}{l}\text { of the adoption of } \\
\text { IFRS in developing } \\
\text { countries? }\end{array}$ & $\begin{array}{l}\text { Student test-t } \\
\text { and } \\
\text { Mann-Whitney } \\
\text { test. }\end{array}$ & countries. \\
\hline $\begin{array}{l}\text { Alami and } \\
\text { Rachid }\end{array}$ & $2010-2013$ & 8 Countries & $\begin{array}{l}\text { What is the effect of } \\
\text { the implementation } \\
\text { of IFRS on the } \\
\text { accounting } \\
\text { information? }\end{array}$ & $\begin{array}{l}\text { Durbin } \\
\text { Watson. }\end{array}$ & $\begin{array}{c}\text { Significant effect. } \\
\text { (Alami and Rachid, 2015) }\end{array}$ \\
\hline $\begin{array}{c}\text { AHSINA } \\
\text { TOUAB and } \\
\text { BOUKARI }\end{array}$ & 2013 & Morocco & $\begin{array}{l}\text { What is the impact } \\
\text { of IFRS on the } \\
\text { reliability and } \\
\text { transparency of } \\
\text { Moroccan financial } \\
\text { statements? }\end{array}$ & $\begin{array}{l}\text { The simple } \\
\text { linear } \\
\text { regression. }\end{array}$ & $\begin{array}{l}\text { There is no significant } \\
\text { difference between the } \\
\text { financial statements under } \\
\text { Moroccan standards and those } \\
\text { prepared under IFRS. }\end{array}$ \\
\hline Haoudi & 2015 & Morocco & $\begin{array}{l}\text { Analyze the IFRS } \\
\text { adoption in } \\
\text { Moroccan context. }\end{array}$ & $\begin{array}{l}\text { Theoretical } \\
\text { analysis. }\end{array}$ & $\begin{array}{l}\text { A financial information of } \\
\text { better quality compared to } \\
\text { Moroccan local standards. }\end{array}$ \\
\hline
\end{tabular}

As we see in Table 2, authors have treated IFRS in several aspects, with different samples, and methods to achieve different results. Despite the importance of these studies, they cover all sectors in their analysis and they are not restricted to analyzing the impact of IFRS on one specific sector. In our case, what makes our study different from those studies is the fact that we focused our work in one specific sector with a recent sample and using the Simple Linear Regression analysis to achieve our results.

\section{Research Methodology}

In this section, we will present the sample selected, then we will list and explain our working hypothesis.

\subsection{Sample Selected}

The sample selected consists of three petroleum and gas companies listed in the CSE which transmitted financial and account statement under the GSCM and the consolidated financial statements under IFRS.

To achieve well-targeted and meaningful results, we decided to limit the research to a single sector, which is the petroleum and gas sector. The choice of Moroccan petroleum and gas sector is due to its dynamic activity globally, and in the Moroccan Stock Market (MSM) in particular.

Our initial sample consists of three petroleum and gas companies listed in the CSE, whose study period is of six years between 2010 and 2015. The choice of three companies as a sample is due to the limited number of petroleum and gas companies in the MSM. In our research, there exist five companies where we only found financial communications of only 
three of them: AFRIQUIA GAS, TOTAL and LA SAMIR. They are three pioneering groups in the Moroccan petroleum and gas sector. Moreover, the choice of an observation base reduced on six years is due to the period from which these groups have begun to introduce the consolidated accounts under IFRS in their financial communications.

However, it is in 2007 that we saw the most of transition to IFRS because since this year the $M S E C$ and the MSM have increased their efforts to control consolidated publications of Moroccan companies and the encouragement of transition to IFRS.

The data on financial communications in our sample were obtained from the Website of the $\mathrm{CSE}^{2}$ and that of Moroccan Stock Market Authority (MSMA) formerly the $M S E C^{3}$ which is available to all visitors.

Table 3. Mean of the accounting and financial data in millions of the sample under the GSC of Morocco and IFRS for 6 years

\begin{tabular}{|c|c|c|c|c|c|c|c|c|c|c|c|c|c|c|}
\hline & & $\begin{array}{l}\text { Fixed } \\
\text { assets }\end{array}$ & $\begin{array}{l}\text { Current } \\
\text { assets }\end{array}$ & $\begin{array}{c}\text { Trea-sury } \\
\text { assets }\end{array}$ & $\begin{array}{l}\text { Total } \\
\text { assets }\end{array}$ & $\begin{array}{c}\text { Permanent } \\
\text { funding }\end{array}$ & $\begin{array}{l}\text { Current } \\
\text { liabilities }\end{array}$ & $\begin{array}{l}\text { Treasury } \\
\text { liabilities }\end{array}$ & $\begin{array}{c}\text { Total } \\
\text { liabilities }\end{array}$ & $\begin{array}{l}\text { Net } \\
\text { profit }\end{array}$ & $\begin{array}{l}\text { Debt } \\
\text { ratio }\end{array}$ & $\begin{array}{l}\text { Current } \\
\text { ratio }\end{array}$ & $\begin{array}{l}\text { Investor } \\
\text { Funding } \\
\text { Ratio }\end{array}$ & $\begin{array}{l}\text { financial } \\
\text { profit-ability }\end{array}$ \\
\hline \multirow{6}{*}{ GSC } & 2010 & 6094 & 5831 & 290 & 12215 & 4639 & 5009 & 2567 & 12215 & 403 & 0,62 & 0,81 & 0,76 & 0,09 \\
\hline & 2011 & 6308 & 7342 & 292 & 13942 & 4727 & 5708 & 3507 & 13942 & 504 & 0,66 & 0,83 & 0,75 & 0,11 \\
\hline & 2012 & 6493 & 8753 & 227 & 15473 & 4700 & 7499 & 3275 & 15473 & 308 & 0,70 & 0,83 & 0,72 & 0,07 \\
\hline & 2013 & 6586 & 8756 & 479 & 15821 & 4690 & 6770 & 4361 & 15821 & 294 & 0,70 & 0,83 & 0,71 & 0,06 \\
\hline & 2014 & 6947 & 8825 & 320 & 16092 & 6963 & 5845 & 3285 & 16092 & 245 & 0,57 & 1,00 & 1,00 & 0,04 \\
\hline & 2015 & 7742 & 9753 & 320 & 17815 & 7715 & 6428 & 3672 & 17815 & 320 & 0,57 & 1,00 & 1,00 & 0,04 \\
\hline \multirow{6}{*}{ IFRS } & 2010 & 6255 & 5893 & 498 & 12645 & 4189 & 6118 & 2339 & 12645 & 274 & 0,67 & 0,76 & 0,67 & 0,07 \\
\hline & 2011 & 6472 & 7438 & 501 & 14411 & 4453 & 6666 & 3292 & 14411 & 478 & 0,69 & 0,80 & 0,69 & 0,11 \\
\hline & 2012 & 6726 & 9012 & 461 & 16199 & 5160 & 7819 & 3220 & 16199 & 380 & 0,68 & 0,86 & 0,77 & 0,07 \\
\hline & 2013 & 6717 & 8690 & 917 & 16324 & 4779 & 7167 & 4353 & 16299 & 267 & 0,71 & 0,83 & 0,71 & 0,06 \\
\hline & 2014 & 12626 & 8956 & 348 & 21929 & 5654 & 8397 & 3212 & 17263 & 316 & 0,74 & 0,80 & 0,45 & 0,06 \\
\hline & 2015 & 16314 & 9885 & 352 & 26550 & 6271 & 9198 & 3613 & 19083 & 399 & 0,76 & 0,80 & 0,38 & 0,06 \\
\hline
\end{tabular}

The data in (Table 3.) above is the data of certain accounting and financial variables. The numbers in the table are numbers in millions for reasons of space and computing facilitation in processing data using the statistical package E- views 7.1.

\footnotetext{
${ }^{2}$ http://www.casablanca-bourse.com/

${ }^{3}$ http://www.cdvm.gov.ma/
} 


\subsection{Our Hypothesis}

Hypothesis 1: Values of financial and accounting information of Moroccan petroleum and gas sector under IFRS are superior to those values under the GSCM.

To make sure that values of financial and accounting information of Moroccan petroleum and gas sector under IFRS are superior to values of accounting and financial information of Moroccan petroleum and gas sector under the GSCM. We use the most classical way, which is the statistical average for its calculation regarding our variables. We add values of all the comments included in a data set, and then we divide them by the number of observations. This calculation provides averages values of all of our data variables. If the number of medium-sized accounting and financial variables in IFRS above, and exceeds the average accounting and financial variables under GSCM the hypothesis will be verified. This hypothesis will be demonstrated in descriptive statistics part.

Hypothesis 2: Values of financial and accounting information of Moroccan petroleum and gas sector under IFRS are evolving in common with those values under the GSCM for our six observations.

To check the joint development of data between IFRS and the GSCM, we based on the correlation coefficient " $r$ " that defines dependence degree between the two standards. This number is in $[-1 ; 1]$ where -1 means strictly inverse changing variables and +1 means strictly parallel evolution. It is equal to the mathematical variables covariance divided by the product of the standard deviations. When the two phenomena have a common evolution, we say that they are "correlated". The correlation here measures the degree of connection between these two phenomena represented by variables. If we have positive correlation coefficient we approve our hypothesis.

Hypothesis 3: The IFRS adoption will have a positive impact on financial and accounting information quality in Moroccan petroleum and gas sector, compared to financial and accounting information under the GSCM.

To test this hypothesis we based on the parameter of the simple linear regression function " $a=\operatorname{Cov}(X, Y) / \operatorname{Var}(X)^{\prime \prime 4}$ which is also the beta of financial analysis. This parameter is calculated using our statistical package E-views for all our variables, to set our model that will be posed in the following hypothesis, if we have more positives parameters than negatives, we say that the hypothesis is verified and the adoption of IFRS have a positive impact on financial and accounting information quality, compared to the GSCM in Moroccan petroleum and gas sector. If it not the case the hypothesis will be rejected.

Hypothesis 4: The majority of accounting and financial variables of the in Moroccan petroleum and gas sector under IFRS can be explained by the same variables under the GSCM in the same sector.

The demonstration is based on the simple linear regression "SLR" and the Student test " $\mathrm{t}$ -statistic " to test this hypothesis in the following working model:

\footnotetext{
${ }^{4} \mathrm{X}$ is the variable due, and $\mathrm{Y}$ is the variable result
} 


$$
\Delta X_{\text {afIFRS }}=C_{1}+C_{2} * \Delta X_{\text {afMar }}
$$

With:

$\Delta \mathrm{X}_{\text {afIFRs: }}$ accounting and financial variables under the International Financial Reporting explained;

$C_{1}$ : Constant;

$C_{2}$ : Called also "a", it is a parameter to measure the impact;

$\Delta \mathrm{X}_{\mathrm{afMar}}$ : Explicable accounting and financial variables under the GSCM.

To show explicability of IFRS variables by the GSCM variables and their significances, we will be based on the student test "t-statistic" if the probability $t$ is less than 0.05 it's significant, if not the case it will be the opposite.

\section{Hypothesis 5: Our model is relevant and meaningful.}

To measure the relevance of our model in its entirety described in equation (1), we based on the adjusted coefficient of determination $\mathrm{R}^{2}$. Regarding the overall significance of this model, we used the Fisher test "F-statistic."

\section{Results and Discussion}

At this section, we verify our hypotheses, starting by presenting the descriptive statistics, measuring the correlation, analyzing the simple linear regression, and then verifying at the end the Relevance and significance of the model, and finally showing main results.

\subsection{Descriptive Statistics}

Based on our sample data above and using the statistical package E-views we could calculate the main elements of descriptive statistics, which are "the mean, median, standard deviation, maximum, minimum, skewness and kurtosis» of our six observations. The reason for its calculations is to show the significance of our simple and to verify our first hypothesis.

Table 4. Descriptive statistics

\begin{tabular}{|c|c|c|c|c|c|c|c|c|}
\hline $\begin{array}{c}\text { Financial and } \\
\text { accounting } \\
\text { variables }\end{array}$ & Observ & Mean & Median & Maximum & Minimum & $\begin{array}{c}\text { Standard } \\
\text { Deviation }\end{array}$ & Skewness & Kurtosis \\
\hline $\begin{array}{c}\text { Fixed assets } \\
\text { (GSC) }\end{array}$ & 6 & 6694.833 & 6539.500 & 7741.000 & 6094.000 & 586.7324 & 0.950968 & 2.74689 \\
\hline $\begin{array}{c}\text { Fixed assets } \\
\text { (IFRS) }\end{array}$ & 6 & 9184.167 & 6721.000 & 16313.00 & 6254.000 & 4260.074 & 0.929505 & 2.130978 \\
\hline $\begin{array}{c}\text { Current assets } \\
\text { (GSC) }\end{array}$ & 6 & 8209.333 & 8754.000 & 9753.000 & 5830.000 & 1397.804 & -0.793442 & 2.427629 \\
\hline $\begin{array}{c}\text { Current assets } \\
\text { (IFRS) }\end{array}$ & 6 & 8311.667 & 8822.500 & 9885.000 & 5892.000 & 1424.206 & -0.779486 & 2.416365 \\
\hline
\end{tabular}




\begin{tabular}{|c|c|c|c|c|c|c|c|c|}
\hline Treasury (GSC) & 6 & 320.8333 & 306.0000 & 478.0000 & 226.0000 & 84.30994 & 1.086921 & 3.290609 \\
\hline Treasury (IFRS) & 6 & 512.3333 & 479.0000 & 917.0000 & 347.0000 & 209.8177 & 1.361636 & 3.498017 \\
\hline $\begin{array}{l}\text { Total assets } \\
\text { (GSC) }\end{array}$ & 6 & 15226.17 & 15647.00 & 17815.00 & 12214.00 & 1928.145 & -0.342996 & 2.268622 \\
\hline $\begin{array}{l}\text { Total assets } \\
\text { (IFRS) }\end{array}$ & 6 & 18009.50 & 16261.50 & 26550.00 & 12645.00 & 5218.347 & 0.726825 & 2.126762 \\
\hline $\begin{array}{c}\text { Permanent } \\
\text { funding (GSC) }\end{array}$ & 6 & $\underline{5572.167}$ & 4713.500 & 7714.000 & 4639.000 & 1388.947 & 0.797181 & 1.756576 \\
\hline $\begin{array}{c}\text { Permanent } \\
\text { funding (IFRS) }\end{array}$ & 6 & 5083.500 & 4968.500 & 6271.000 & 4188.000 & 779.0031 & 0.399136 & 1.892947 \\
\hline $\begin{array}{c}\text { Current } \\
\text { liabilities (GSC) }\end{array}$ & 6 & 6209.167 & 6136.000 & 7498.000 & 5008.000 & 877.7053 & 0.135888 & 2.031527 \\
\hline $\begin{array}{c}\text { Current } \\
\text { liabilities (IFRS) }\end{array}$ & 6 & 7560.500 & 7492.000 & 9198.000 & 6118.000 & 1138.772 & 0.180184 & 1.809337 \\
\hline Treasury (GSC) & 6 & $\underline{3443.833}$ & 3395.500 & 4360.000 & 2566.000 & 586.5821 & 0.103876 & 2.640524 \\
\hline Treasury (IFRS) & 6 & 3337.500 & 3255.500 & 4352.000 & 2338.000 & 653.6179 & 0.049270 & 2.713423 \\
\hline $\begin{array}{c}\text { Total liabilities } \\
\text { (GSC) }\end{array}$ & 6 & 15226.17 & 15647.00 & 17815.00 & 12214.00 & 1928.145 & -0.342996 & 2.268622 \\
\hline $\begin{array}{c}\text { Total liabilities } \\
\text { (IFRS) }\end{array}$ & 6 & 15982.67 & 16248.50 & 19082.00 & 12645.00 & 2236.162 & -0.179558 & 2.161372 \\
\hline Net profit (GSC) & 6 & 345.1667 & 313.5000 & 503.0000 & 244.0000 & 92.92452 & 0.788179 & 2.400375 \\
\hline Net profit (IFRS) & 6 & 352.3333 & 348.0000 & 478.0000 & 267.0000 & 81.82094 & 0.382909 & 1.858899 \\
\hline Debt ratio (GSC) & 6 & 0.636667 & 0.640000 & 0.700000 & 0.570000 & 0.059554 & -0.079293 & 1.374837 \\
\hline $\begin{array}{c}\text { Debt ratio } \\
\text { (IFRS) }\end{array}$ & 6 & 0.708333 & 0.700000 & 0.760000 & 0.670000 & 0.035449 & 0.415300 & 1.679045 \\
\hline $\begin{array}{c}\text { Current ratio } \\
\text { (GSC) }\end{array}$ & 6 & $\underline{0.883333}$ & 0.830000 & 1.000000 & 0.810000 & 0.090701 & 0.683089 & 1.502589 \\
\hline $\begin{array}{c}\text { Current ratio } \\
\text { (IFRS) }\end{array}$ & 6 & 0.808333 & 0.800000 & 0.860000 & 0.760000 & 0.033714 & 0.191203 & 2.381068 \\
\hline $\begin{array}{c}\text { Investor Funding } \\
\text { Ratio (GSC) } \\
\end{array}$ & 6 & $\underline{0.823333}$ & 0.755000 & 1.000000 & 0.710000 & 0.138082 & 0.650789 & 1.500106 \\
\hline $\begin{array}{c}\text { Investor Funding } \\
\text { Ratio (IFRS) }\end{array}$ & 6 & 0.611667 & 0.680000 & 0.770000 & 0.380000 & 0.157533 & -0.619782 & 1.689214 \\
\hline $\begin{array}{c}\text { financial } \\
\text { profitability } \\
(\mathrm{GSC})\end{array}$ & 6 & 0.068333 & 0.065000 & 0.110000 & 0.040000 & 0.027869 & 0.368893 & 1.801636 \\
\hline $\begin{array}{c}\text { financial } \\
\text { profitability } \\
\text { (IFRS) }\end{array}$ & 6 & 0.071667 & 0.065000 & 0.110000 & 0.060000 & 0.019408 & 1.545113 & 3.746652 \\
\hline
\end{tabular}

As is shown in Table 4, the numbers of averages are in bold which concern IFRS are more than the average in underline which concern averages on the GSCM, in other words nine bold 
averages against four underlines averages. So hypothesis 1 is verified. This is due to several reasons. One of them is the method of evaluating assets, based on the fair value under IFRS and on the historical cost in Morocco.

\subsection{Correlation Measure}

To measure the correlation, we used the correlation coefficient " $r$ " which allows us to see if there is a positive or negative correlation. In other words, it allows us to measure the dependence degree between two standards "Moroccan and international". The correlation measure here is the basis of given planted above and it is calculated using the statistical package e-views.

Table 6. Correlation measure

\begin{tabular}{|c|c|c|}
\hline Financial and accounting variables & R & Correlation type \\
\hline Fixed assets & 0.9522 & Positive \\
\hline Current assets & 0.9973 & Positive \\
\hline Treasury & 0.7863 & Positive \\
\hline Total assets & 0.8912 & Positive \\
\hline Permanent funding & 0.9073 & Positive \\
\hline Current liabilities & 0.4693 & Positive \\
\hline Treasury & 0.9947 & Positive \\
\hline Total liabilities & 0.9947 & Positive \\
\hline Net profit & 0.5549 & Positive \\
\hline Debt ratio & -0.6663 & Negative \\
\hline Current ratio & -0.1220 & Negative \\
\hline Investor Funding Ratio & -0.9785 & Negative \\
\hline financial profitability & 0.8566 & Positive \\
\hline
\end{tabular}

We found that the majority of measured variables have a positive correlation between the two standards "Moroccan and international", ten bolds correlations types against three underlines correlations types, so hypothesis 2 is verified. The correlation remains an excellent instrument to measure the quality of dependency and development between the two phenomena. This is due to the evolution in the sector itself.

\subsection{Simple Linear Regression Analysis}

The Simple Linear Regression analysis, allows us to verify the third and the fourth hypothesis, thanks to our following model:

$$
\Delta X_{\text {afIFRS }}=C_{1}+C_{2} * \Delta X_{\text {afMar }}
$$

From this model we calculated the parameter $\mathrm{C}_{2}$ which allows us to measure the impact of IFRS on financial and accounting information quality in Moroccan petroleum and gas sector. We calculated the parameter $\mathrm{C}_{2}$ for all variables, and then we saw if positive variables $\mathrm{C}_{2}$ outweigh negative ones to prove our third hypothesis. For the fourth hypothesis which concerns variables dependence between IFRS on GSCM variables, we based on Student's 


\section{Ml Macrothink}

Business and Economic Research

ISSN 2162-4860

2016, Vol. 6, No. 1

statistical test, where we show the significance of accounting and financial variables by comparing probabilities by Student's test that must be less than 0.05 to be significant.

Table 6. Student test- $\mathrm{t}$ and the regression parameter

\begin{tabular}{|c|c|c|c|c|c|c|}
\hline $\begin{array}{c}\text { Financial and accounting } \\
\text { variables }\end{array}$ & $\mathrm{C}_{1}$ & $\mathrm{C}_{2}$ & Impact & t-Statistic & Prob(t-statistic) & Inter-t \\
\hline Fixed assets & -37102.57 & 6.913799 & Positif & 6.235991 & 0.0034 & Significant \\
\hline Current assets & -30.39144 & 1.016168 & Positif & 27.31248 & 0.0001 & Significant \\
\hline Treasury & -115.5549 & 1.957054 & Positif & 2.546086 & 0.0636 & $\underline{\text { Not significant }}$ \\
\hline Total assets & -18715.39 & 2.411959 & Positif & 3.929426 & 0.0171 & Significant \\
\hline Permanent funding & 2247.968 & 0.508874 & Positif & 4.315842 & 0.0125 & Significant \\
\hline Current liabilities & 3779.749 & 0.608898 & Positif & 1.062939 & 0.3477 & $\underline{\text { Not significant }}$ \\
\hline Treasury & -479.7631 & 1.108434 & Positif & 19.44503 & 0.0002 & Significant \\
\hline Total liabilities & -1583.512 & 1.153684 & Positif & 19.48048 & 0.0001 & Significant \\
\hline Net profit & 183.6734 & 0.488633 & Positif & 1.334179 & 0.2530 & $\underline{\text { Not significant }}$ \\
\hline Debt ratio & 0.960846 & -0.396617 & Negatif & -1.787093 & 0.1485 & $\underline{\text { Not significant }}$ \\
\hline Current ratio & 0.848420 & -0.045381 & $\underline{\text { Negatif }}$ & -0.246014 & 0.8178 & $\underline{\text { Not significant }}$ \\
\hline Investor Funding Ratio & 1.530864 & -1.116434 & $\underline{\text { Negatif }}$ & -9.508062 & 0.0007 & Significant \\
\hline financial profitability & 0.030901 & 0.596567 & Positif & 3.320838 & 0.0294 & Significant \\
\hline
\end{tabular}

According to calculations developed by using the statistical package e-views, first its shows that majority of accounting and financial variables in the petroleum and gas sector have a positive parameter $\mathrm{C}_{2}$ (ten bolds against three underlines), which mean that there is a positive impact of IFRS on financial and accounting information quality in Moroccan petroleum and gas sector, and then shows that eight variables have a significant probability against five. Thus verifies our third and fourth hypothesis, which is due to the continuous evolution of IFRS and while GSCM is not changing.

\subsection{Relevance and Significance of Our Model}

To measure the relevance of our model, we based on the " $\mathrm{R}^{2}$ " adjusted coefficient of 
determination. This number belongs to the real interval $[0 ; 1]$ where it is irrelevant if it close to 0 and it is relevant if it close to 1 . As regards the overall significance of the model in general, it is based on the statistical test of Fisher, if the probability is less than 0.05 the model is significant if it is more than 0.05 it will be not the case.

Table 7. Fisher test-F and the adjusted coefficient of determination

\begin{tabular}{|c|c|c|c|c|c|}
\hline $\begin{array}{c}\text { Financial and accounting } \\
\text { variables }\end{array}$ & $\begin{array}{c}\text { F-statistic } \\
\text { (Fisher) }\end{array}$ & Prob(F-statistic) & F-Interpretation & $\mathrm{R}^{2}$ adjusted & Relevance \\
\hline Fixed assets & 38.88759 & 0.003369 & Significant & 0.883416 & Relevant \\
\hline Current assets & 745.9717 & 0.000011 & Significant & 0.993333 & Relevant \\
\hline Treasury & 6.482554 & 0.063569 & Not significant & 0.523017 & Irrelevant \\
\hline Total assets & 15.44039 & 0.017111 & Significant & 0.742803 & Relevant \\
\hline Permanent funding & 18.62649 & 0.012488 & Significant & 0.779020 & Relevant \\
\hline Current liabilities & 1.129840 & 0.347722 & Not significant & 0.025311 & Irrelevant \\
\hline Treasury & 378.1094 & 0.000041 & Significant & 0.986915 & Relevant \\
\hline Total liabilities & 379.4892 & 0.000042 & Significant & 0.986962 & Relevant \\
\hline Net profit & 1.780035 & 0.253035 & Not significant & 0.134953 & Irrelevant \\
\hline Debt ratio & 3.193702 & 0.148452 & Not significant & 0.304948 & Irrelevant \\
\hline Current ratio & 0.060523 & 0.817780 & Not significant & -0.231369 & Irrelevant \\
\hline Investor Funding Ratio & 90.40325 & 0.000683 & Significant & 0.947036 & Relevant \\
\hline financial profitability & 11.02797 & 0.029356 & Significant & 0.667287 & Relevant \\
\hline
\end{tabular}

As it shown in Table 7 and by using the statistical package E-views, we see that the majority of variables have a determination coefficient close to 1 and a probability of Fisher's test less than 0.05 , which approves our last hypothesis that concerns the relevance and significance of the model.

\subsection{Main Results}

The main results of this study are:

Values of financial and accounting variables of Moroccan petroleum and gas sector under IFRS are superior to values of accounting and financial information of Moroccan petroleum and gas sector under the GSCM. Which is due to several reasons, one of them is the method of evaluating assets, based on the fair value under IFRS and on the historical cost in Morocco;

- Values of financial and accounting information of Moroccan petroleum and gas sector under IFRS are evolving in common with values of accounting and financial information of Moroccan petroleum and gas sector under The GSCM for our six observations. This is due to the evolution of the sector itself;

- IFRS adoption has a positive impact on financial and accounting information quality in Moroccan petroleum and gas sector, compared to the financial and accounting information under the GSCM. Which due to the continue evolution of IFRS from on the GSCM that has not changed; 
- The majority of accounting and financial variables of the in Moroccan petroleum and gas sector under IFRS is explained by the accounting and financial variables under the GSCM in the same sector. This is explained by the dependence of consolidated financial statements under IFRS with the financial statements under the GSCM.

Table 8 . Validity of hypothesis

\begin{tabular}{|c|l|c|}
\hline Number & \multicolumn{1}{|c|}{ Hypothesis } & Result \\
\hline Hypothesis 1 & $\begin{array}{l}\text { Values of financial and accounting information of Moroccan petroleum and gas sector } \\
\text { under IFRS are superior to those values under the GSCM. }\end{array}$ & validated \\
\hline Hypothesis 2 & $\begin{array}{l}\text { Values of financial and accounting information of Moroccan petroleum and gas sector } \\
\text { under IFRS are evolving in common with those values under the GSCM for our six } \\
\text { observations. }\end{array}$ & validated \\
\hline Hypothesis 3 & $\begin{array}{l}\text { The IFRS adoption will have a positive impact on financial and accounting information } \\
\text { quality in Moroccan petroleum and gas sector, compared to financial and accounting } \\
\text { information under the GSCM. }\end{array}$ & validated \\
\hline Hypothesis 4 & $\begin{array}{l}\text { The majority of accounting and financial variables of the in Moroccan petroleum and gas } \\
\text { sector under IFRS can be explained by the same variables under the GSCM in the same } \\
\text { sector. }\end{array}$ & validated \\
\hline Hypothesis 5 & $\begin{array}{l}\text { Our model is relevant and meaningful. } \\
\text { validated }\end{array}$ \\
\hline
\end{tabular}

\section{Conclusion}

In this article we presented the results of an empirical study of three petroleum and gas companies listed in the CSE to measure IFRS adoption impact on financial and accounting information quality in Moroccan petroleum and gas sector, and to see how the majority of the accounting and financial variables of this sector under IFRS dependents on those variables under the GSCM.

This study can be a pioneer in this type of research in Moroccan petroleum and gas sector.

However, the results of our study should be taken with caution because of limitations of our research. Two major methodological reasons and limitations must be mentioned: The small size of the sample is three groups, the choice of three companies as a sample is due to the limited number of petroleum and gas companies in the MSM. In our investigation it was found just five companies which have been found the financial communications of only three companies, and the second one is the limited number of observations "six", which is also due to the recent introduction of IFRS and the no obligation to these groups to develop financial communications under IFRS in Morocco.

In this regard, (Nobre, 2001) states that there may be a significant gap between rhetoric and actual practice. However, this limit is present in all quantitative studies based on traditional data collection.

Many lines of research are possible: The development of such a study on other sectors. 


\section{References}

Ahsina, K., Taouab, O., \& Cherqaoui, M. B., (2014). L'impact de l'adoption des IFRS sur les sociétés cotées à la bourse de Casablanca: une étude exploratoire. Rev. Gest. Organ. 6, 75-83. http://dx.doi.org/10.1016/j.rgo.2014.09.003

Alali, F. A., \& Foote, P. S., (2012). The Value Relevance of International Financial Reporting Standards: Empirical Evidence in an Emerging Market. Int. J. Account. 47, 85-108. http://dx.doi.org/10.1016/j.intacc.2011.12.005

Alami, Y., \& Rachid, O. M., (2015). Evidence of the Impact of Methods of Implementation of IFRS on the Relevance of Accounting Information. Bus. Econ. Res. 5, 227-242. http://dx.doi.org/10.5296/ber.v5i1.6467

Boukari, M., \& Richard, J., (2007). Les incidences comptables du passage des groupes français cotés aux IFRS. Comptab. - Contrô - Audit Tome 13, 155-169. http://dx.doi.org/10.3917/cca.133.0155

CGI, R., n.d. OIL \& GAZ report CGI [WWW Document]. URL https://www.cgi-group.co.uk/sites/default/files/files_uk/brochures/12s_factsheet.pdf (accessed 4.18.16).

Elhamma, A., (2012). Comprendre les normes comptables internationales IAS/IFRS au Maroc: cours simplifié, exemples illustratifs et exercices corrigés. EDGL print.

Haoudi, K., (2015). Transition to IFRS in Morocco: Theoretical Foundations, benefits and issues. Int. J. Innov. Appl. Stud. 10, 1299-1311.

Susana Callao, J. I. J., (2007). Adoption of IFRS in Spain: Effect on the Comparability and Relevance of Financial Reporting. J. Int. Account. Audit. Tax. 16, 148-178. http://dx.doi.org/10.1016/j.intaccaudtax.2007.06.002

\section{Copyright Disclaimer}

Copyright for this article is retained by the author(s), with first publication rights granted to the journal.

This is an open-access article distributed under the terms and conditions of the Creative Commons Attribution license (http://creativecommons.org/licenses/by/3.0/). 